\title{
Magyar női teniszezők elégedettségvizsgálata és a sportág életpályamodellként való megvalósítása az infokommunikáció fejlődésének tükrében
}

A nemzetközi sportot hosszú évtizedeken keresztül hagyományosan a nyugati nemzetek uralták. A tenisz népszerűsége emelkedett, a társadalmi elit arisztokratikus szórakozásából a középosztály sportjává vált. Ezzel párhuzamosan a sportágban megjelenő lehetőségek is megnőttek, mára milliárdos üzlet lett. A tenisz világszerte az egyik legsikeresebb női sport, a női teniszezők a legjobban fizetett sportolók közé tartoznak. A volt szocialista országok játékosai egyre nagyobb szerepet vállalnak a profi sportággá fejlődött globális teniszben. A tanulmány leírja a jelenség okait, középpontba állítva a már visszavonult és a ma is aktív elit magyar teniszező nőket. A kutatást a már visszavonult (n1=27), illetve az aktív (n2=20) magyar elit teniszezőnők körében tettük meg. Az adatgyüjtést kérdőíves módszerrel végeztük. A statisztikai elemzés igazolja, hogy a női teniszezők sportteljesítményének és sportkultúrájának vizsgálatában a játékosok elégedettségét differenciált tényezők befolyásolják. A tanulmány egyik fő következtetése, hogy a teniszkarrier már életpályamodellként is funkcionál.

Kulcsszavak: hivatásos tenisz, magyar női játékosok, eredményesség

\section{Szerzői információ}

Kincses Gábor, Budapesti Műszaki és Gazdaságtudományi Egyetem Gazdaság- és Társadalomtudományi Kar Testnevelési Központ, Testnevelési Egyetem Doktori Iskola https//:orcid.org/0000-0003-4176-6718

Ormos Mihály, Eötvös Loránd Tudományegyetem Gazdaságtudományi Kar Pénzügy és Számvitel Tanszék, Selye János Egyetem Gazdaságtudományi és Informatikai Kar Közgazdaságtan Tanszék https//: orcid.org/0000-0002-3224-7636

Bartha Zsolt, Budapesti Műszaki és Gazdaságtudományi Egyetem Gazdaság- és

Társadalomtudományi Kar Testnevelési Központ, Pécsi Tudományegyetem Egészségtudományi Kar Bargwet Egészségtudományi Doktori Iskola https//:orcid.org/0000-0002-9539-0923

Így hivatkozzon erre a cikkre:

Kincses Gábor, Ormos Mihály, Bartha Zsolt. „Magyar női teniszezők elégedettségvizsgálata és a sportág életpályamodellként való megvalósítása az infokommunikáció fejlődésének tükrében”.

Információs Társadalom XXI, 3. szám (2021): 9-25.

—https://dx.doi.org/10.22503/inftars.XXI.2021.3.1 


\section{Examining the satisfaction of Hungarian female tennis players in planning the tennis sport as a career model}

International sports are dominated by Western nations for many decades. The popularity of tennis has risen from the aristocratic entertainment of the elite upper class to the sport of the middle class. Tennis is one of the most successful women's sports worldwide, the female tennis players among the highest paid athletes. Players from the former socialist countries are taking on an increasing role inglobal tennis, which has developed into a professional sport. The article describes the causes of the phenomenon focusing on the already retired and still active elit hungarian women tennis players. The research was carried out among retired and active Hungarian elite tennis players. Data was collected with the help of questionnaries. Statistical analysis confirms that the success of tennis players' sports performance and sports culture is influenced by different factors. The main contribution of our paper is that a tennis career already functions as a livelihood model.

Keywords: professional tennis, hungarian women players, effectiveness 


\section{Bevezetés}

Az 1960-as évektől kezdődően az úgynevezett „open era”-nak köszönhetően a tenisz sportágba begyürüző üzleti jelenlét jelentősen nőtt, amely nem csupán a játékosok számának növekedésével, hanem a sportágban rejlő profitszerzési lehetőségek széleskörü skálájával is indokolható. A szponzorok és befektetők üzleti terveit és annak eredményességét nagyban befolyásolják az általuk támogatott játékosok sikerességmutatói és a teniszhez kapcsolódó sportrendezvények bevételei. A hosszú távon és folyamatosan eredményes teniszjátékos sportpályafutása során nem csupán tetemes anyagi bevételre tesz szert, de az iparág többi résztvevőjének is jelentős hasznot indukál (Barget 2005).

Az igazán sikeres játékosok nem csupán kiváló eredményeket érnek el a sportágukban, de sikereiket a játékukon kívül más járulékos formában (szponzori díjak, reklámok, meghívásos versenyek stb.) is tudják kamatoztatni. Számos kutatás foglalkozik a női tenisz történeti fejlődésével, a játékosok hírességgé válásával, a szponzori lehetőségekkel (Lough 1996; Shuart 2004; Antunovic 2016). Egyes tudósok vizsgálták a női sportolók, köztük a teniszezők pénzkereseti lehetőségeit (Clement 1987; Che 2013) továbbá a teniszkarrier lehetséges hosszát, az ideális életkort, valamint a versenytenisztől való visszavonulás okait (Schultz et al. 1988; Allison et al. 1988; Otis 2006; Rodenber 2013; Casagrande 2018). Különös figyelmet szenteltek elit francia és svéd sportolók - köztük teniszezők - összehasonlításánál a karrier utáni visszavonulás indikátoraira és az atléták által megélt elégedettségi mutatókra. Tanulmányuk kimutatta, hogy az élsportból való kilépés a civil életbe egy több szinten zajló, többdimenziós folyamat, melyben a hovatartozás és a kultúra is jelentős szerepet játszik (Stambulova et al. 2007).

A kutatás célja, hogy feltárja azokat az összefüggéseket, amelyek leginkább jellemzik és befolyásolják a női teniszjátékosok eredményesség faktorait. Az alapvető cél, annak felmérése, hogy Magyarországon a visszavonult és az aktív női versenyzők sikeres eredményeinek hátterében milyen tényezők állnak, és ezek hogyan hatnak a tenisz üzleti vonatkozásaira, valamint a sporthoz kapcsolódó életpályamodellre.

A jelenlegi elemzés egy olyan doktori kutatási téma része, amely a tenisz sportág üzleti vonzatainak átfogó vizsgálatát tűzte ki feladatul. A mostani tanulmány több faktor mentén vizsgálja a magyar női játékosok sikerét és személyes elégedettségét volt és jelenlegi karrierjük viszonylatában.

Az első részben áttekintésre kerülnek a teniszsport hazai és nemzetközi vonatkozásai, ízelítőt adva az elmúlt század valóságáról, a szocialista országok tenisz sportágának fejlődéséről - nagy figyelmet szentelve az infokommunikáció előretörésének - napjainkig bezárólag. A második részben bemutatásra kerülnek a felmérések és elemzések módszertani eszközei, a kapott eredmények és azok értékelése.

\section{A tenisz hazai és nemzetközi vetületei}

\subsection{0. századi valóság}

A szovjet típusú társadalmi és gazdasági berendezkedésben a döntéseket a bürokraták hozták, így a volt szocialista tagállamokban is, mint Magyarország. A sport 
sem volt kivétel ez alól. A legfelsőbb vezetés direkt módon, minisztériumokon és bázisvállalatokon keresztül támogatta a legjobb sportolókat. Az elit sport maximálisan élvezte a bizalmat, hiszen a nemzetközi versenyeken elért sikerek a szocialista társadalmat voltak hivatottak dicsőíteni. Főleg az olimpiai sportágak versenyzőit segítették, akiknek ugyan hivatalosan volt munkahelyük, de ezeken a helyeken ténylegesen nem kellett dolgozniuk. Egyetlen feladatuk volt: az edzéseken a legjobb formába lendülve szállítani a győzelmeket, és megteremteni a jó gyári hangulatot, ami persze fokozta a dolgozók munkakedvét és jó irányba mozdította a termelékenységet (Sterbenz és Géczi 2016).

Az 1952 és 1988 között megrendezett olimpiai játékokon az összesített éremtáblázatok legjobb 10 helyezettje versenyében számos kelet-európai ország volt megtalálható. Ezek, az akkori szocialista országok a sportolással kapcsolatos összes költséget fedezték. Folyamatosan képezték a sportolókat, szervezték a versenyeket és fizették a háttérintézetek kiadásait is. A versenyzők remek létesítményekben készülhettek, anyagi előnyöket, kapcsolati tőkét élveztek, élsportolóként beutazhatták az egész világot (Poupaux 2005).

Természetesen azokban az országokban, ahol a politika nem szólt bele a sportágak választásába, hierarchiájába, ahol sikerült megőrizni a világháborúk előtti tradíciókat, könnyebb volt a helyzet, szemben a volt szocialista országokkal, ahol - kivéve talán Csehszlovákiát - kicsit nehezebb volt lépést tartani a fejlődéssel. Magyarországon a tenisz nagyon sokáig kifejezetten a felsőbb társadalmi osztályba tartozók által játszott, fehér sportnak számított, a szocializmus időszakában egyáltalán nem támogatták központilag.

Az 1980-as években egy vidéken teniszező nő egyik legnagyobb álma az volt, hogy egy nagy, patinás fővárosi klubba igazoljon. Ha a magyar ranglistán előkelő helyet foglalt el, válogatott versenyző volt, megkülönböztetett figyelmet érdemelt. A budapesti egyesületek minden téren előnyt jelentettek. Az infrastrukturális lehetőségek sokkal jobbak voltak. A sportág szezonjellege átalakult. Sokáig csak szabadtéren lehetett edzeni és versenyezni, télen a teniszezők valamilyen kondíciót fenntartó, havas sportágat üztek. Budapesten azonban a hideg hónapokban már légtartásos sátrakban és kifejezetten fedett pályáknak épült létesítményekben lehetett ütni a labdát. Pár klubban versenyeket is rendeztek, ahol a salakhoz képest sokkal gyorsabb kemény borításon vagy szőnyegen lehetett mérkőzéseket játszani, fejlődni. A magyar női teniszjátékosok többsége egyesületi sportállásban tevékenykedett. Jó fizetéssel rendelkeztek, edzésre és versenyre jártak. A legnagyobb hazai megmérettetésnek az Országos Bajnokság és a klubok közötti tavaszi-őszi rendszerben lebonyolított Csapatbajnokság számított. Egyéb, a játékhoz szükséges összes feltétellel rendelkeztek, az edzőt, az ütőt a klub biztosította számukra. A versenyek nevezési díjait, szállás- és étkezési költségeit a szakosztály fizette, és az elért eredmények arányában év végi jutalmat kaptak. A válogatott teniszezők ezen felül külföldi tornákra is eljutottak a magyar Szövetség szervezésében eleget téve a meghívó ország feltételeinek.

A szakosztályokban dolgozó adminisztrátorok a levélalapú kommunikációt használták, bélyeget ragasztva a borítékra, a postaládába dobták a nevezéseket. Ha valamit nagyon sürgősen akartak elintézni, a postára rohanva feladtak egy táviratot a 
lemaradt névvel a vidéki versenyre, és reménykedtek, hogy az időben megérkezik. Telefonon azt az edzőt vagy játékost tudták utolérni, akinek háztartásában fellelhető volt a készülék. Sok családnak évekig kellett várnia, és ha szerencsések voltak, megkapták a kiutalást. Nagy örömet jelentett a számukra továbbá, ha valamely szomszéddal ikervonalhoz jutottak. Kezdetben egy-, később kétforintos érmével az utcai nyilvános fülkéből három percig intézhették az ügyeiket.

Ebben az időszakban a családok fekete-fehér televíziójukban követhették a sporteseményeket. Néha felvillant egy-egy akkori teniszsztár az esti híradó sportösszefoglalójában pár másodpercre egy labdamenet erejéig. A kevésbé fáradt sportrajongók ezt a néhány képkockát a második és a harmadik ismétlésben is megtekintették, mielőtt lefeküdtek. Valamikor az 1970-es évek végén kezdték el közvetíteni a magyar televízióban a világ legnagyobb teniszversenyét, a kéthetes wimbledoni bajnokság utolsó négy napján lejátszott elődöntőket és döntőket.

\subsection{Kelet-európai fordulat}

Látni kell, hogy a tenisz minden társadalomban beágyazott. Annak ellenére, hogy az 1989-es rendszerváltás előtti és utáni időszak nem tartozik szorosan a tanulmány témájához, néhány mozzanatot mégis érdemes megemlítenünk. A szovjet típusú, állami irányítású sportmodell kezdett kiégni a világgazdaságban bekövetkezett változásoknak köszönhetően. 1985-ben elkezdődött a sportágazat átalakítása. Nagyobb szabadságot engedélyeztek a klubok számára, magánfinanszírozók jelentek meg a sport körül, akik nagyobb mozgásteret kaptak. A szocialista országok labdajátékosai hivatalos engedélyekkel nyugati és észak-amerikai profi csapatokhoz szerződhettek. A kontraktokban megállapított eladási összegeket az engedélyt adók elosztották az anyaklub és az állami sportbizottság között. Az 1990-es évek elején megreformálták a sportért felelős szervezeteket. Jogszabály-módosításokat hajtottak végre a globális nemzetközi változásokat követve. A versenyzők már tömegesen hagyták el hazájukat a jobb megélhetés reményében. Otthon már nem volt kifizetődő főállású sportolónak lenni (Poupaux 2005).

1989-ben a világ 36 országában marxista-leninista pártok voltak hatalmon. Ekkor a történelem kivételes lehetőséget teremtett a cselekvésre. A legtöbb országban a magánszektornak köszönhetően a gazdaság szerkezete átalakult, bár a reformok stop-go ciklusokban zajlottak. A felzárkózás a legjobb mutatókkal rendelkező országokban is lassabban mentek végbe a kezdeti elképzelésekhez képest. Végül 10 kelet-európai ország az EU tagja lett. A változások egész Európában egyértelmúen a Szovjetunió felbomlásával indultak el (Mihályi 2014).

Az 1989-90-es magyarországi rendszerváltás a tenisz sportágat sem kerülte el. Szinte az összes budapesti egyesület megszűnt - igaz, hála a régi legendás kluboknak és edzőknek, mindig fel tudtunk mutatni nemzetközileg is elismert játékosokat. Az egész országban végbemenő gazdasági rendszerváltást kevés élte túl. Megszűnt a játékosok „sportállása”, egyik napról a másikra bizonytalanná vált a megélhetésük. Az állami források kiapadtak, a klubokat magukra hagyták, a vállalatokat privatizálták. A sport alrendszer lassú és bonyolult folyamatokon ment keresztül, a felszínre 
kerülő új, vállalkozói réteg főleg családi érintettség révén finanszírozta egyesek karrierjét (Földesi 1996).

A sportban próbáltunk a nyugati típusú modernizációra áttérni, de az öröklött intézményrendszer ezt nagyban befolyásolta. Az üzleti szektor ebben az időben hazánkban nem volt érdekelt a sporttámogatásban és nem is érdeklődött iránta. A sport, így a tenisz is, nem üzleti alapon müködött (Földesi 2005).

Az 1990-es években olyan sportágakban értünk el sikereket a világban, mint az öttusa, a vívás, a kajak-kenu, a vízilabda vagy a súlyemelés. A fejlett piacgazdaságban élő nyugati országok ezekkel nem véletlenül nem foglalkoztak, hiszen nem láttak bennük semmilyen üzleti potenciált. A televízióban nehezen közvetíthető, alacsony reklámértékkel rendelkező versenyek nem feleltek meg a piacracionalitás törvényeinek. A magyar sport modernizációjának legnagyobb gondja a kontraszelektivitásában rejlett. Míg a szocializmusban a bürokratikus koordinációnak köszönhetően az ország gazdasági eredményeihez képest nagylelkűen támogatták az élsportot, a professzionalizálódó, üzleti alapokkal rendelkező versenysportot nem sikerült új pályára állítani. Jogi szabályozás hiányában kialakulatlan volt a média és a versenysport kapcsolata, a reklámpiac törvényi rendezése és a közvetítési jogok rendszere (Fóti 1996).

\subsection{A tenisz evolúciója}

Az egyéni hivatásos sport üzleti szerkezetében és müködésében is fontos szerepet játszik a szórakoztatóiparnak való megfelelés. Azoknak a sportolóknak, akik ebből élnek, folyamatosan olyan teljesítményt kell nyújtaniuk, hogy a nézők örömmel és elkötelezetten legyenek hajlandók egyre többet fizetni a felejthetetlen produkciókért ezzel biztosítva a játékosok egzisztenciáját. Minél izgalmasabb a pályán a kiélezett küzdelem és minél tovább kérdéses a győztes kiléte, annál izgalmasabb a mérkőzés a szurkoló számára (Kassay 2020).

A tenisz a 20. század második felében vált hivatásos sportággá. A profi játékosok megalakították a szövetségeiket, a női teniszezők 1973-ban a WTA-t, (Women’s Tennis Association). A magánfinanszírozás megjelent a sportágban, a versenyek egyre színvonalasabbak és élvezhetőbbek lettek. A szövetségek nagyobb befolyásra tettek szert - ezzel védve a játékosok érdekeit. A támogatók pedig potenciális üzleti lehetőséget láttak a kialakult helyzetben. A legnagyobb, úgynevezett Grand Slam versenyeken elért győzelmek számítanak a legnagyobb elismerésnek. Ahhoz, hogy a Grand Slam teljesüljön, egymás után kell nyerni egy naptári éven belül az Ausztrál Openen, a Roland Garroson, Wimbledonban és a US Openen.

Az évnek nincs olyan hete, amikor a világ valamelyik pontján ne szerveznének valamilyen szintű versenyt. Az évtizedek óta kialakult naptárba nagyon nehéz új versennyel jelentkezni, hiszen a rendezvények nagy százalékban rentábilisak. Az előbb már említett Ausztrál Open fő támogatója a KIA, dél-koreai autógyár. A cég 2002-től stratégiai partnerként remek lehetőséget lát a teniszversenyben. Az ausztrál sport történetének leghosszabb és legnagyobb szponzori szerződésével rendelkezik, amit 2023-ig hosszabbítottak meg. A versenyrendezés kapcsán olyan gazdasági 
hatások mérhetők, amelyek stabilizálják a rendező város, Melbourne pozícióját és segítik az egész ország sporttőkéjének növekedését. Gyakorlati tény, hogy a sportág népszerüsége globálisan emelkedik, köszönhetően a jól felépített szabályrendszernek, a szponzorok folyamatos támogatásának, üzleti elégedettségének és a játékosok káprázatos teljesítményének. Ezért az évről-évre nyerhető pénzdíjak összege folyamatosan növekszik (Kincses, Ormos és Bartha 2019).

A 2019-es Ausztrál Openen a rendezők extraprofitra tettek szert. A verseny alatt közel 800 ezer jegy talált gazdára, 7\%-al több, mint az előző évben. Az Ausztrálián kívüli televíziós adások 900 milliónál több otthont értek el. A rendezők 30,4 terabyte forgalmat bonyolítottak a világhálón keresztül, ezzel fokozva a szurkolói élményt a tömegek számára. A szervezők legfontosabb szervezeti prioritása volt az adatok kiaknázása fokozva ezzel az innováció jelentőségét. A nézők így tudtak okosabb döntéseket hozni igényeik maximális kielégítése érdekében (Kincses, Ormos és Bartha 2021).

A már korábban említett Grand Slam versenyek televíziós közvetítési jogaival, reklám és egyéb hirdetési lehetőségeivel kapcsolatos összes elvárásnak szigorúan meg kell felelni a Nemzetközi Tenisz Szövetség (ITF) által előírt szabályokban foglaltaknak. Deklarálva van, hány helyi szponzor engedélyezett, hány hirdetést helyezhetnek el a pályán, de fel kell festeni például a tornát rendező város nevét is a pályaborításra. A labdaszedőknek és a vonalbíróknak egységes öltözetet kell viselniük, a pálya végében, jól látható helyen, el kell helyezni egy órát (Gáspár 2012).

A világ legnagyobb vállalatai, akik jó időben és jó helyen kapcsolódtak be a tenisziparba, évtizedek alatt busásan kamatoztatták invesztícióikat. Előzetes költség-haszon számítások alapján fektettek be hatalmas összegeket a teniszversenyek támogatásába ezzel emelve a tornák színvonalát a hozzáadott érték szempontjából is. Ezek a cégek az egyre erősebbé váló szövetségekkel karöltve dollármilliókat tettek be a vállalkozásba, hiszen a tenisz folyamatosan szállította a jó játékosokat. Megfelelő egyensúlyt tudtak kialakítani az egész éves versenynaptárt tömörítő szervezet fő támogatójával és a versenyt rendező város helyi szponzoraival az összköltségeket illetően. Például az Ausztrál Open kapcsán a helyiek számára elengedhetetlen, hogy fenntartsák az egyensúlyt a multinacionális, egész világot behálózó óriáscégek és az országon belüli, számukra nagyon fontos támogatók között. Ezzel segítve őket a jobb ismertséghez és az újabb piacok megszerzéséhez. A turizmus fejlődését tartják szem előtt, különös tekintettel az ázsiai csendes-óceáni területekre. Az erős gazdasági előnyök következtében új munkahelyeket tudtak létrehozni Melbourne és Victoria állam számára. A teniszverseny sikeres megrendezésén túlmenően nagy figyelmet fordítanak az idegenforgalmi haszon kialakítására is. Ezért az egész nyarat kitöltő fesztiválszerü élményt nyújtanak, ahol Melbourne kultúráját is láthatóvá teszik ezzel vonzóbbá téve városukat a világban (Kincses, Ormos és Bartha 2020).

A 2020. évi összdíjazás meghaladta a 71 millió ausztrál dollárt, ami 13,6 \%-os emelkedést mutatott az előző esztendőhöz képest. A játékosok által hazavihető öszszegek az elmúlt 20 évben 412\%-al növekedtek. A női verseny 128-as főtáblájának első fordulós vesztese is 90.000 dolláros csekket kapott. A versenyrendezők a támogatók segítségével megteremtik a lehetőséget az alacsonyabban rangsorolt játékosoknak is, hogy elutazzanak a kontinensre, és az őket segítőket is fizetni tudják. Ezzel próbálják egalizálni a feltételeket a még izgalmasabb mérkőzések kialakulására már 
a korai fordulókban is biztosítva a közönség folyamatos szórakoztatását (Kincses, Ormos és Bartha 2021).

\subsection{Az IT térnyerése}

Ahogy a tudomány sok területén, az infrastruktúrális fejlődés jelentős hatást gyakorolt a sportra is. A sportágak többségében a technológia térnyerése erős magyarázó változója a teljesítménynek, ahogy a sportot körülvevő környezet megváltozása magyarázhatja magának a sportágnak a változását. Az egyik legjelentősebb ilyen környezeti tényező a média, amelynek elmúlt évtizedekben tapasztalt fejlődése a teniszre is nagy hatást gyakorolt. A világ az internet elterjedésével a technológia hirtelen felgyorsult fejlődésével, a globalizált piac kiszélesedésével teljesen megváltozott. A tenisz mint eladható szolgáltatás, és azok a termékek, amelyekkel és amelyekben a játékot űzik jelentősen felértékelődtek. Egy nagy verseny kínálata megtalálja és eléri a fogyasztót, a tenisz esemény minden igényt kielégít. Mindez megfelel a keresleti oldalon található vevő elvárásainak és értékrendjének. Akár a helyszínen, akár a televízió képernyője előtt izgulja végig a meccset, felejthetetlen élményben részesül. A modern média csatornáin keresztül ez a szórakozási lehetőség több százmillió emberhez jut el, a legnézettebb mérkőzések milliárdon felüli követőre találnak. A verseny rendezői hihetetlen számú rajongóhoz tudják eljuttatni a mérkőzéseket egy időben a televíziós sportcsatornákon és a szociális médiumokon keresztül, amit természetesen a legfejlettebb technológiák megléte biztosít. Ezért is növekedhetnek évről-évre a versenyek pénzdíjai, hiszen a támogatók, a tévétársaságok, a reklámozók is emelik a szponzori összegeket. A televízió megsokszorozza a fogyasztói tömeget, így a tenisz mint a világ egyik legnépszerűbb sportága közel 200 ország megszámlálhatatlan rajongójához tudja eljuttatni a hirdetések üzeneteit.

Ezen felül a mindennapokban rengeteg felületen lehet kommunikálni a fogyasztókkal, legyen szó az internetről vagy a közösségi média nyújtotta platformokról. Ennek különböző válfajai a fizetett, a saját vagy a szerzett médiaoldalak. Az emberek részt vesznek az online szóbeszédben, megosztanak információkat, ajánlásokat tesznek, lájkolják a nekik tetsző posztokat és kommenteket írnak. A marketingkommunikáció a sztárok segítségével hosszú időre ébren tartja az érdeklődést, ezzel generálva a rendezési költségek megtérülését. Az eseményt követő külföldi így ismeri meg és tudja beazonosítani a rendező országot. Az információáramlás a csatorna jellege tekintetében lehet hagyományosan reklám, szórólap vagy valamilyen ajánlás. Online pedig az összes ismert keresőben fellelhető weboldalakon keresztül (Papp-Váry és Farkas 2018).

A big data egy olyan összefoglaló megnevezés, mely az online platformon jelenik meg, és a folyamatosan digitalizálódó környezetünk dinamikus adatelemző módszereit generálja. Az infokommunikációs technológiák mobilizálásával lehetőségünk van az adatok és az innováció hatalmának kiaknázására. A digitális hálózatok kereszttüzében azonosítani tudjuk a humán ágenseket, akik blokkolják vagy befolyásolják a dinamikát. Az információkat minden esetben kiegészíthetjük viselkedési elemzésekkel vagy egyéb felmérésekkel. A hálózati beágyazottságot azonban 
nagyban befolyásolják azok a zajok, amik a tartalmak és az adatok felől érkeznek (Fehér 2014).

A partnerek figyelmének felkeltése és lekötése nagyon fontos versenytényező a szolgáltatások testreszabását illetően. Az internet úgy is felfogható, mint a figyelem sajátos piaca. Elkerülhetetlen az információs túlterheltség, ugyanakkor a napi keresések száma eléri az 5 milliárdot. A legutóbbi időkben externáliaként kell vizsgálni az információszennyezést, melynek formái a vírusoktól a nem kért reklámokig számolatlanok. Az infokommunikációs piac legnagyobb kihívása, hogyan tudjuk kiszürni az információáradatból az arra értékeseket. A hiteles információk közvetítésében nagy szerepe van a híres sportolóknak, akik támogatóik révén, reklámokban szerepelve tudják átadni a vállalat arculatát, és ismertté tenni a terméket. A 21. században számos új technológia alakítja a reklámtevékenységet. Több új és gyors hirdetési csatorna jelent meg az okostelefonoktól a közösségi médiáig. A reklámelhelyezési felületek eltolódnak az újak javára háttérbe szorítva a korábbiakat. A fogyasztói szokások átalakulásának következtében a vállalatok reklámüzenetei már az internetes keresőben találhatóak meg, nem a televízióban. 2020-ban az egész világon 5,2 milliárd ember használt valamilyen mobileszközt és 3,8 milliárd csatlakozott a közösségi hálózatokhoz (Hámori 2021).

\subsection{Magyar tenisz napjainkban}

A 2000-es évekhez közeledve Magyarországon kialakult az a vállalkozói réteg, amely nemzetközi, pénzdíjas teniszversenyeket szervezett és rendezett Magyarországon, ezzel játéklehetőséget nyújtva a versenyzők számára. A közelmúlttól napjainkig a mai generáció versenyképessége megsokszorozódott a nemzetközi mezőnnyel szemben. Feltételeik sokkal jobbak a maguk elé tűzött célok elérése érdekében. Megszűnt a papíralapú kommunikáció, a versenyekre a játékosokat e-mailben nevezik egyetlen gombnyomással. Az összes, tornákkal kapcsolatos információt megtalálják az interneten. A mérkőzéseket élőben lehet követni a szociális médián keresztül. A Magyarországon is fogható sportcsatornák kínálata minden igényt kielégít. A mai gyerekek folyamatosan élőben láthatják kedvenceik mérkőzéseit. A meccsek statisztikái elérhetőek abban a pillanatban, ahogy az események megtörténnek. A globalizáció és az elérhető olcsó repülőjegyek jóvoltából a ranglistán egyre feljebb kerülő versenyzők eljutnak a világ minden tájára, hogy gyarapíthassák világranglista-pontjaikat. A győztes mérkőzések befejezése után pedig a zsebükből előhúzott okostelefon segítségével az alkalmazásoknak köszönhetően ingyen tudják szeretteikkel közölni a jó hírt.

A magyar hivatásos versenysport stratégiai ágazattá nyilvánítása óta alapjaiban változtak meg a finanszírozási feltételek. Ugyan a tenisz nem tartozik a látványsportok közé, kiemelt támogatásban részesül. A közvetlen és közvetett forrásokból lehet új programokat indítani, infrastruktúrát fejleszteni, bővíteni a versenyzési lehetőségeket (Kassay 2020).

2017-ben a Magyar Tenisz Szövetség közel 4 milliárd forintból gazdálkodott, nyolcszor többől, mint 2014-ben. ATP és WTA tornát rendezett Magyarországon, 
30\%-ra leszorítva az állami támogatást. Az MTSZ-nek 263 tagszervezete van, a Budapest-Vidék aránya 35-65\%. A kiemelt sportágfejlesztési program keretében a Szövetség saját forrásából és egyéb szponzori bevételekből évi 0,5-1 millió forint támogatást tud biztosítani a játékosoknak. A WTA és ATP világranglistán legjobb helyezéseket elért női és férfi teniszezőknek ennél az összegnél jóval többet. Ezen felül a Davis Kupában (férfi csapatverseny), valamint a Federation Kupában (női csapatverseny) aratott győzelmeik viszonylatában a résztvevők még bónuszjuttatásokban is részesülnek (Milliárdok a magyar teniszben 2017).

A fenti adatokból leszűrhető, hogy a mai magyar női és férfi teniszezők összehasonlíthatatlanul jobb anyagi és tárgyi feltételek között tudják felvenni a versenyt elődeikhez képest. A mai generációnak minden lehetősége adott ahhoz, hogy tehetségüket kibontakoztatva sok örömöt tudjanak okozni saját maguknak és a nekik szurkoló teniszrajongóknak.

\section{Kérdőíves felmérés és módszertan}

A vizsgálatba két célcsoportot vontunk be. A már visszavonult (n1=27) és ma is aktív (n2=20) női játékosokat. Az adatgyüjtés mindkét vizsgált csoportban kérdőíves módszerrel történt. A kérdőívet a próba kérdezések tapasztalatai alapján állítottuk össze és véglegesítettük. A visszavonult játékosok valamennyien e-mail-címükre kapták meg a kérdőívet, majd kitöltés után visszaküldték. Az aktív versenyzők, elsősorban az edzők közreműködésével, személyesen kapták meg a kérdőívet. Összesen tehát 47 megválaszolt ív érkezett hozzánk, (N=47). A kérdőív megválaszolása mindkét csoportban önkitöltéses módszerrel történt.

A visszavonult teniszezők közül kutatásunkba azokat kívántuk bevonni, akik pályafutásuk során korosztályos vagy felnőtt válogatottak voltak, részt vettek nemzetközi pénzdíjas versenyeken és már visszavonultak a versenyzéstől. A Magyar Tenisz Szövetség adatbázisát és nyilvántartását figyelembe véve, a már visszavonult teniszezőnők tekintetében a teljes csoport 43 főből állt, 40-et sikerült megtalálnunk, és 27 fő töltötte ki a kérdőívet (n1=27).

Az aktív teniszezők közül azokat vontuk be a vizsgálatba, akik eddigi pályafutásuk során vagy indultak már felnőtt női bajnokságon, vagy a fiatalabb korosztályba tartoznak, de már indulási jogosultságot szereztek, és részt vettek nemzetközi pénzdíjas versenyeken is. A Tenisz Szövetség nyilvántartása alapján 30 játékos felelt meg ezeknek a kritériumoknak, vagyis a csoport 30 főből állt, közülük 20 versenyző töltötte ki a kérdőívet (n2=20). Leíró statisztikai módszereket alkalmaztunk.

\section{Eredmények}

\subsection{Profi évek és eredményesség}

Egy tanulmány szerint a sikeres nemzetközi profi teniszezők átlagéletkora minden évvel növekszik. A vizsgálat rámutat arra, hogy a világ 100 legjobb férfi és női te- 
niszezőjének átlagéletkora jelentősen nőtt az elmúlt 10 évben. A világranglisták az 1970-es évekbeli megjelenése óta a vezető játékosok átlagéletkora 2018-ban volt a legmagasabb. Az utóbbi két évben ez a korhatár valamivel csökkent, mert a most 30-40 éves korosztályt lassan új tehetségek váltják fel, akik közül nem egy még nem töltötte be 25. életévét.

Harminc évvel ezelőtt a világ 100 legnépszerübb férfi és női teniszező átlagos életkora 23,74 év, illetve 22,56 év volt. Csak az elmúlt 10 évben az átlagéletkor 2,67 évvel nőtt a férfiak és 2,14 évvel a nők körében. A fejlett fitneszrendszerek, valamint a tudomány és a táplálkozás terén elért haladás, a nyereményalapok növekedése, arra ösztönözi a játékosokat, hogy folytassák a versenyt (The numbers prove it: tennis players are getting older 2020).

A vizsgálatba bevont visszavonult játékosok (n1=27) valamikor a magyar női teniszutánpótlás élvonalába tartoztak, 14-en voltak elsők a magyar korosztályos ranglistákon, közülük 10-en a felnőttek mezőnyében is kimagaslóan jó eredményeket értek el. A világranglistán 7-en voltak a legjobb 100 versenyző között.

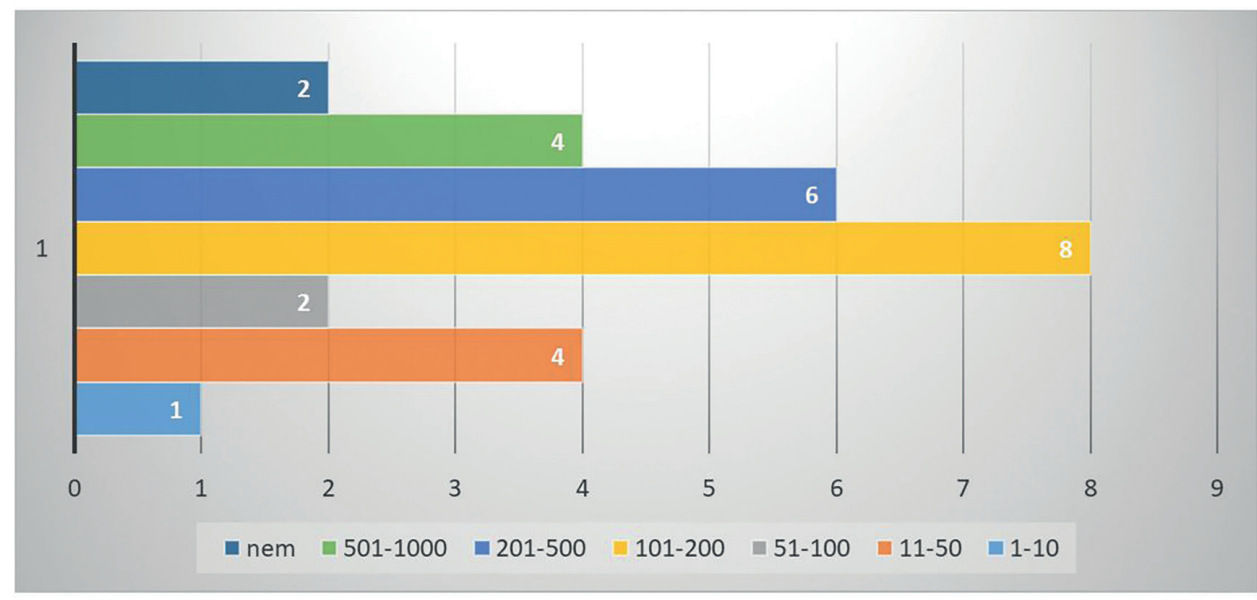

1.ábra: Visszavonult játékosok világranglista helyezései (saját szerkesztés)

A felmérés alapján a visszavonult játékosok 15,5 éves korukban játszották első nemzetközi profi versenyüket. Ennek két magyarázata van. Az egyik, hogy a WTA mint a női versenyeket szervező nemzetközi szövetség a 14 éves korhatárt szabta meg limitként. A másik ok, hogy a nemzetközi élvonalba akkor betört teniszezőnők, így Steffi Graf 17 évesen, Szeles Mónika 16 évesen, Martina Hingis pedig 15 évesen már nemzetközileg is kiemelkedően sikeres játékos volt. Ha összehasonlításképpen megnézzük a mai versenyzők átlagéletkorát, fordított tendenciát figyelhetünk meg. Az élvonalbeli játékosok többsége már betöltötte a 30. életévét is, egyre jobban kitolódik az aktív versenyévek száma. A magyar, már visszavonult női játékosok a felmérés alapján átlagban közel 9 évig versenyeztek, és 24,4 évesen már befejezték a profi pályafutásukat. 


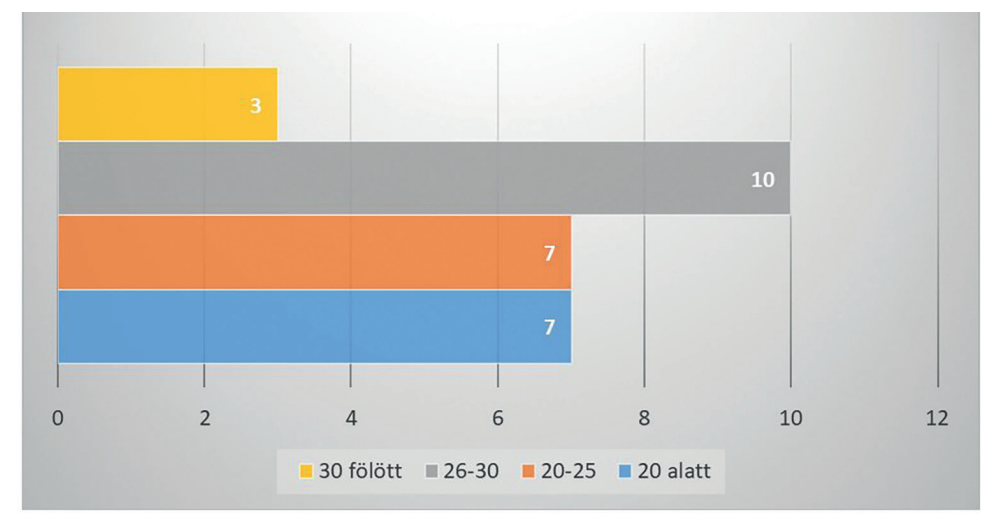

2.ábra: Életkor szerinti profi versenyzői pályaelhagyás (saját szerkesztés)

Az ő esetükben legtöbbször a korai pályaelhagyás indoka olyan lehetőségek elfogadása volt, amely segítette tanulmányaikat elsősorban amerikai egyetemeken. A játéktudás, amivel már 18 évesen rendelkeztek, megfelelt a követelményeknek ahhoz, hogy több éves tanulmányi és sportösztöndíjat kapjanak. Közülük többen családot alapítottak, és ott is telepedtek le.

A felmérésbe bevont ma is aktívan játszó elit magyar női teniszezők (n2=20) többségükben már a 2000-es években születtek. Közülük heten vezettek valamilyen korosztályos ranglistát, ugyanakkor a magyar felnőtt ranglistán nagy szórással helyezkednek el.

Az aktív játékosok átlagban ugyanannyi évesen $(15,6)$ játszották le első profi versenyüket, mint a visszavonultak $(15,5)$. A mai versenyzők a felmérés alapján azt tervezik, hogy 12 évig fognak játszani nemzetközi hivatásos tornákon. Az aktív versenyzők legalább átlagban 30,5 éves korukig szeretnének teniszezni, ami hat évvel hosszabb, mint a visszavonultak esetében $(24,4)$.

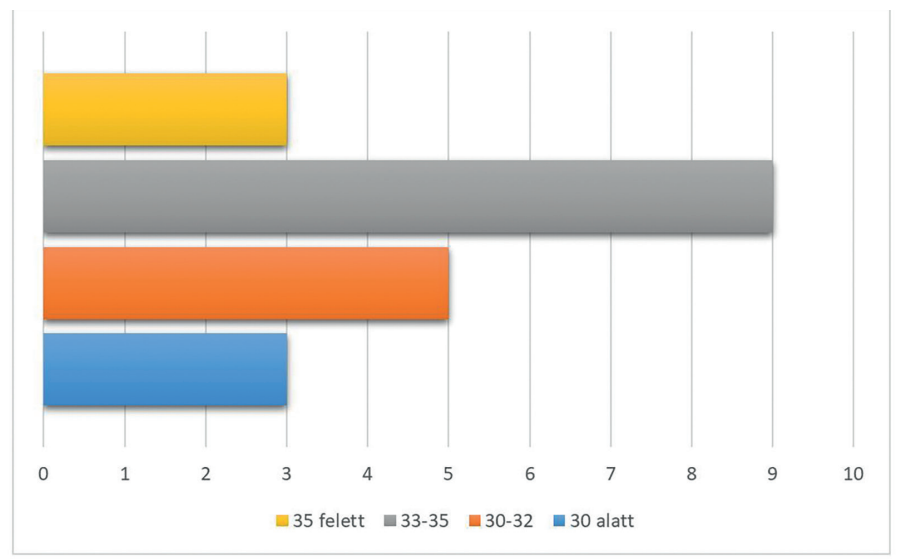

3.ábra: Aktív játékosok tervezett profi életútja (saját szerkesztés) 


\subsection{Versenyzők elégedettség elemzése}

Az elégedettség felmérésekor az alábbi kérdésekre vártunk válaszokat visszavonult és aktív játékosok esetében.

Kérdések a visszavonult játékosokhoz:

1. Összességében elégedett vagy a tenisz karriereddel?

2. Összességében szerinted megérte a hosszú évek alatt befektetett idő, pénz és energia?

3. Ha ma lennél gyerek, újra végigcsinálnád ugyanezt?

Kérdések az aktív játékosokhoz:

1. Összességében elégedett vagy az eddig elért sikereiddel?

2. Összességében az eddig elért eredményeidhez képest szerinted megérte a hosszú évek alatt befektetett idő, pénz és energia?

3. Ha ma lennél gyerek, újra végigcsinálnád ugyanezt?

A 27 egykori kiváló magyar teniszezőből 21 (78\%) elégedett karrierjével, csak 4-en válaszoltak nemmel, 2-en pedig bizonytalan választ adtak. Arra a kérdésre, hogy megérte-e a befektetett munka, energia, edzés, idő és pénz, csupán 3-an válaszoltak nemmel, 23 fő igennel, 1 fő bizonytalan választ adott. Ez nagyon jó aránynak számít, ami azt jelenti, hogy karrierjük során olyan élményeket éltek át, amelyek egész életükre kihatással voltak. Ha ma lennének gyerekek, 23 fő újra végigcsinálná a teniszjátékosi éveket, 4-en viszont nem vállalnák újra.

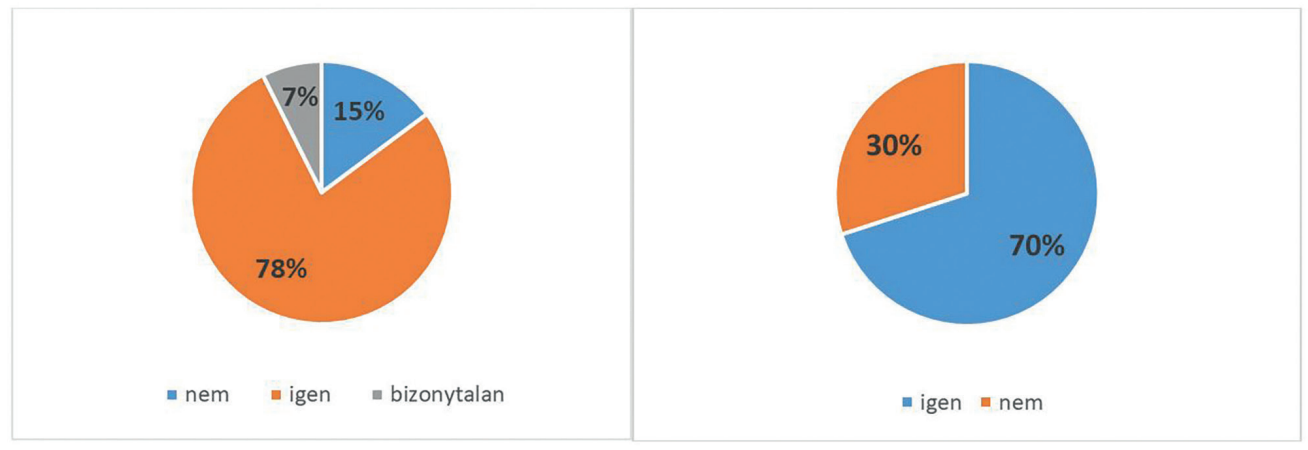

4.ábra: Visszavonult és aktív játékosok elégedettsége

(saját szerkesztés)

A 20 ma is aktív teniszező válaszaiból kiderül, hogy 70\% elégedett eddig teljesített pályájával, többen bizonytalannak mutatkoztak, nem tudták eldönteni hol tartanak, milyen célokat dédelgetnek még. Számukra nagyon nehéz volt meghatározni a viszonyítási alapot, azaz hogy ki mihez képest méri saját maga elégedettségét, ha nem állnak rendelkezésre sikerességi mérőszámok. 18 válaszadó véleménye, hogy az eddigi évek befektetett munkája, energiája, pénze megérte a sok fáradságot, 2-en nem biztosak benne, hogy mással kellett volna tölteniük az időt. 19 igen válasz született 
arra a kérdésre, hogy még egyszer belevágnának-e a teniszkarrier építésbe, ha ma lennének gyerekek. Tehát annak ellenére, hogy néhányan még nem elégedettek az elért eredményeikkel, lényegében az összes játékos szívesen újrakezdené a karrierjét.

\subsection{Pályafutás befejezése utáni tevékenység}

A pályafutás befejezése utáni tevékenység is fontos a sportkarrier-építés szempontjából. A felmérés arra vonatkozott mind a két célcsoport esetében, hogy a teniszjátékban eltöltött sportolói évek után milyen további tevékenységeket folytatnak a visszavonult versenyzők, illetve hogy a jelenleg aktívak mit képzelnek el a versenyzés után.

A kérdések a két célcsoport esetében a következők voltak:

Visszavonultak:

Pályafutásod befejeztével közel maradtál a sportághoz? Ha igen, manapság milyen szerepet tölt be az életedben a tenisz?

Aktívak:

Pályafutásod majdani befejeztével közel szeretnél maradni a sportághoz? Ha igen, milyen szerepet töltene be az életedben a tenisz?

A visszavonultak közül (n1=27) 21 teniszező közel maradt a sportághoz, és manapság is jelentős szerepet tölt be életében a tenisz. A válaszokból azt tünik ki, hogy sokan egyidejűleg több funkcióban is tevékenykednek, azaz nemcsak edzők, hanem sport- vagy teniszklubot is vezetnek és saját gyereküket segítik az előttük álló teniszfeladatok megoldásában (teniszmamák).

Az aktív teniszezők (n2=20) válaszaiból kiderül, hogy a visszavonulásuk utáni elképzeléseikre szélesebb spektrumban érkeztek válaszok. 11-en közülük edzői feladatokat vállalnának, 8-an valamilyen menedzseri pozíciót képzelnek el, akár sportvagy klubvezetőként. 3-an teniszmamai feladatokat is ellátnának. 3-an pedig nem a tenisz körül képzelik el a civil életüket. Ebben a felmérésben több egyidejü funkció megjelölésére is lehetőség volt.

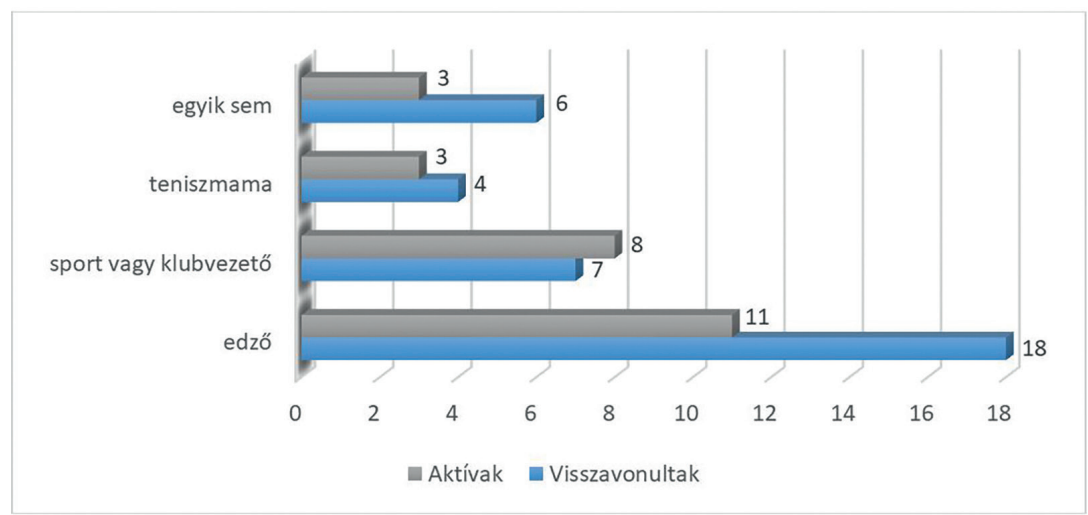

5.ábra: Visszavonult és aktív játékosok versenyzés befejezése utáni tevékenységei (saját szerkesztés) 


\section{5. Összegzés}

A profi játékosok térhódításával napjainkig kialakultak azok a versenyrendszerek, amelyekben a játékosok ezrei mérettetik meg magukat és egy nagyon korrekt és kiszámítható szisztémában azért küzdenek, hogy győzelmeikkel minél több pontot szerezve egyre előkelőbb helyezést érjenek el a világranglistákon. Az infokommunikáció fejlődésével, a nemzetközi hálózatosodás kiterjesztésével megnövekedett az információcsere hatékonysága. Az infrastrukturális változások lehetővé teszik a sporttevékenység intenzívébbé válását. A médiafelületek sokszínűségével az adatvezérelt innováció megsokszorozta hatalmát.

Tanulmányunkban a már visszavonult és a ma is aktívan játszó magyar elit női teniszezők elégedettségszintjét vizsgáltuk. A kapott eredmények azt sugallják, hogy a két célcsoport közti generációs különbségek jól tükrözik a nemzetközi tendenciákat és azt bizonyítják, hogy a sportághoz kapcsolódó tevékenységek nem csupán az aktív versenyzési szakaszban jelentenek anyagi előnyöket, hanem a tenisz sport életpályamodellként való érvényesülése is jelentős hangsúlyt kap. A felmérések azt mutatják, hogy a két csoportban a közel egyenlő sikereket elérő teniszezők számos ponton hasonló elveket vallanak a karrierjüket illetően.

A tenisz üzleti aspektusait vizsgáló átfogó doktori kutatásunk kapcsolódó vonatkozású eredményei is azt támasztják alá, hogy a sportágválasztásnál a tenisz „művelése”, már nem csupán a versenyzési szakaszból áll, hanem a legtöbb sportoló esetében jól tervezett életpályaként merül fel a karriertervezésében. A tenisz több szempontból is komoly iparággá vált az „open era” után és ennek egyik hozadéka, hogy a személyes sportsikerek hasznosítása az aktív versenyzői szakasz után is jellemző. Az idevonatkozó kutatás egyéb eredményeiről más jövőbeni publikációink fognak beszámolni.

\section{Irodalom}

Allison, Maria és Carrie Meyer. "Career Problems and Retirement Among Elite Athletes: The Female Tennis Professional.” Sociology of Sport Journal no. 5 (1988): 212-222.

Antunovic, Dunja. "You Had to Cover Nadia Comaneci: Points of Change in Coverage of Women's Sport.” The International Journal of the History of Sport 33, no. 13 (2016): 15511573. https://doi.org/10.1080/09523367.2016.1254623.

Barget, Eric. “The Economics of Tennis.” In Wladimir Andreff és Stefan Szymanski (Szerkesztők). Handbook on the Economics of Sport, 418-434. UK: Edward Elgar, 2005.

Casagrande, Pedro de Orleans, Danilo Reis Coimbra és Alexandro Andrade. "Burnout in Elite Tennis Players of Different Junior Categories.” Sports Physchology 24, no. 2 (2018): 121-124. https://doi.org/10.1590/1517-869220182402181208. 
Che, XiaoGang és Brad Humphreys. "Earnings and Performance in Women's Skiing." In Michael Leeds és Eva Marikova Leeds (Szerkesztők). Handbook on the Economics of Women in Sports, 115-131. UK: Edward Elgar, 2013.

Clement, Annie. "Professional Female Athletes: Financial Opportunities.” Journal of Physical Education \& Dance 58, no. 3 (1987): 37-40.

https://doi.org/10.1080/07303084.1987.10609540.

Fehér Katalin. „Digitálisidentitás-stratégiák az online adat -és tartalomhálózatokban és a közösségi médiában.” Jel-Kép: Kommunikáció, Közvélemény, Média no.2 (2014)

DOI: 10.20520/Jel-Kep.2014.2.10

Fóti Péter. „Az üzlet behatolása a magyar sportba.” Valóság 39, no.5 (1996): 14-28.

Földesi Szabó Gyöngyi. „A magyar sport átalakulása az 1989-1990-es rendszerváltás után.” In Földesi Szabó Gyöngyi (Szerkesztő). A magyar sport szellemi körképe, 13-52. Budapest: OTSH-MOB, 1996.

Földesi Szabó Gyöngyi. A magyar sport átalakulása a politikai és gazdasági rendszerváltás időszakában 1985-2004. Budapest: MTA, 2005.

Gáspár Petra. A Grand Slam tenisztornák összehasonlítása, szervezése és lebonyolítása. Veszprém: Pannon Egyetem, 2012.

Hámori Balázs. „A figyelem ökonómiája.” Közgazdasági Szemle 68, no.1 (2021): 96-124.

Kassay Lili. „A tudatosan választott és működtetett üzleti modell kívánatos volta a hivatásos csapatsportban.” In Gősi Zsuzsanna és Bukta Zsuzsanna (Szerkesztők). A sport társadalmi, gazdasági és utánpótlás-nevelési kérdései, 18-35. Budapest: Akadémiai, 2020.

Kincses Gábor, Ormos Mihály és Bartha Zsolt. „Tenisz és üzlet.” In Reisinger Adrienn, Kecskés Petra, Buics László, Berkes Judit és Balassa Bernadett (Szerkesztők). Kulturális gazdaság, 1-9. Győr: Széchenyi István Egyetem, 2019.

Kincses Gábor, Ormos Mihály és Bartha Zsolt. "Retired and Active Hungarian Elite Women Tennis Players' Successfulness in the Light of Tennis Becoming a Business.” Magyar Sporttudományi Szemle 21, no. 88 (2020): 37-44.

Kincses Gábor, Ormos Mihály és Bartha Zsolt. „Az üzlet szerepe a teniszsportban.” Magyar Sporttudományi Szemle 22, (2021) (megjelenés alatt).

Lough, Nancy. “Factors Affecting Corporate Sponsorship of Women’s Sport.” Sport Marketing Quaterly 5, no. 2 (1996): 11-19.

Mihályi Péter. „Mérlegen a rendszerváltás 25 éve.” Közgazdasági Szemle 61, (2014): 898-922.

Otis, C., M. Crespo, C. Flygare, P. Johnston, A. Keber, D. Lloyd-Kolkin, J. Loehr, K. Martin,

A. Quinn, P. Roetert, K. Stroia és P. Terry. "The Sony Ericsson WTA Tour 10 year Age Eligibility and Professional Development Review.” British Journal of Sports Medicine 40, no. 5 (2006): 464-468.

https//: doi/10.1136/bjsm.2005.023366.

Papp-Váry Árpád és Farkas Máté. „Az országmárka-kommunikáció lehetséges eszközei és csoportosításuk a POE-modell alapján.” ME.DOK. Média-Történet-Kommunikáció 13, no. 4 (2018): 19-40.

Pompaux, S. "Soviet and Post Soviet Sport.” In Wladimir Andreff és Stefan Szymanszki (Szerkesztők). Handbook of Economics of Sport, 316-323. UK: Edward Elgar, 2005.

Rodenberg, Ryan. “The Goals and Impacts of Age Restrictions in Sports.” In Michael Leeds és Eva Marikova Leeds (Szerkesztők). Handbook of the Economics of Women in Sport, 156-167. UK: Edward Elgar, 2013. 
Schulz, Richard és Christine Curnow. "Peak Performance and Age Among Superathletes: Track and Field, Swimming, Baseball, Tennis and Golf.” Journal of Gerontology 43, no. 5 (1988): 113-120. https://doi.org/10.1093/geronj/43.5.P113.

Shuart, Joshua. "The Media Dichotomy of Sports Heroes and Sport Celebrities: The Marketing of Professional Women's Tennis Players.” In (Szerkesztők). Proceedings of the 2003 Northeastern Recreation Research Symposium, 145-151. Newtown Square, PA, US, 2004.

Stambulova, Natalia, Stephan Yannick és Ulf Japhag. "Athletic Retirement: A Cross-National Comparison of Elite French and Swedish Athletes." Psyhology of Sport and Exercise 8, no.1 (2007): 101-118. https://doi.org/10.1016/j.psychsport.2006.05.002.

Sterbenz Tamás és Géczi Gábor. Sportmenedzsment. Budapest: Testnevelési Egyetem, 2016.

Tennishead. “The Numbers Prove it: Tennis Players are Getting Older.” Utolsó hozzáférés: 2020. december 5 .

https://tennishead.net/the-numbers-prove-it-tennis-players-are-getting-older/.

Világgazdaság. „Milliárdok a magyar teniszben.” Utolsó hozzáférés: 2020. december 5. https:// www.vg.hu/penzugy/milliardok-magyar-teniszben-537521/. 